\title{
Changes in carbohydrates accumulation in Viguiera discolor Baker in response to water deficit
}

\author{
- $\underline{\text { Rodrigo Fazani Esteves Sanches }}^{1,2}$, Ana Paula Oliveira da Silva ${ }^{1}$, Vanessa Pires da Costa ${ }^{1}$, \\ Maria Ângela Machado de Carvalho ${ }^{1}$ and Emerson Alves da Silva ${ }^{1,2}$
}

Received: 8 April 2019; accepted: 26 August 2019

\begin{abstract}
How to cite: Sanches, R.F.E., Silva, A.P.O., Costa, V.P., Carvalho, M.A.M. \& Silva, E.A. 2019. Changes in carbohydrates accumulation in Viguiera discolor Baker in response to water deficit. Hoehnea 46: e382019. http://dx.doi.org/10.1590/22368906-38/2019.
\end{abstract}

\begin{abstract}
Changes in carbohydrates accumulation in Viguiera discolor Baker in response to water deficit). Water stress is an environmental factor that can regulate growth, limit production and lead to physiological and biochemical changes. Plants present a series of adaptive responses to drought, such as osmotic adjustment, in which carbohydrates play an important role. To evaluate the influence of water deficit on carbohydrates accumulation in $V$. discolor, the plants were divided into two groups: daily watering and water suppression for 14 days being re-watering after this period. Leaves and roots were collected at $0,3,6,9,12,15$ and 18 days, for ecophysiological and biochemical analyzes. Variations in carbohydrate contents in $V$. discolor showed a close relationship with changes in the plant water status, with higher concentrations of soluble sugars, total fructans, oligosaccharides, reducing sugars coinciding with the lower values of soil moisture and leaf water potentials and relative water content. In the tuberous roots, there is an increase in carbohydrate concentrations after re-watering. The increase of these low molecular weight carbohydrates is involved in osmotic adjustment and therefore acts to protect against dehydration.
\end{abstract}

Keywords: Cerrado, drought, fructans, osmoregulation, tuberous roots

RESUMO - (Alterações no acúmulo de carboidratos em Viguiera discolor Baker em resposta ao déficit hídrico). O estresse hídrico é um fator ambiental que pode regular o crescimento, limitando a produção e levando a alterações fisiológicas e bioquímicas. Plantas apresentam uma série de respostas adaptativas a seca, tal como ajustamento osmótico, nos quais os carboidratos desempenham um importante papel. Avaliamos a influência do déficit hídrico no acúmulo de carboidratos em $V$. discolor, nas quais foram divididas em dois grupos: rega diária e restrição de água por 14 dias sendo reidratadas após esse período. Folhas e raízes foram coletados nos tempos: 0, 3, 6, 9, 12, 15 e 18 dias após o início da restrição hídrica, para análises ecofisiológicas e bioquímicas. As variações nos teores de carboidratos em $V$. discolor mostrou uma estreita relação com alterações no estado da água da planta, com concentrações mais elevadas de açúcares solúveis totais, frutanos totais, oligossacáridos, açúcares redutores que coincidem com os menores índices de potenciais hídricos do solo e folhas, assim como menor teor relativo de água foliar. Nas raízes tuberosas, observa-se aumento nas concentrações de carboidratos após retorno das regas. $\mathrm{O}$ aumento desses carboidratos de baixo peso molecular está envolvido no ajuste osmótico e, consequentemente, atua na proteção contra a desidratação.

Palavras-chave: Cerrado, frutanos, osmorregulação, raíz tuberosa, seca

\section{Introduction}

Water stress is one of the most important environmental factors that regulates plant growth and development, limits production (Jones \& Corlett, 1992) and causes physiological and biochemical changes in plants (Zobayed et al. 2007). Thus, plant survival under stressful conditions depends to some extent to sense the stimulus, generate and transmit signals, initiating physiological and biochemical adjustments (Bohnert \& Jansen 1996).

Plants shows several types of responses to drought which contribute to the maintenance of

1. Instituto de Botânica, Núcleo de Pesquisa Fisiologia e Bioquímica de Plantas, Av. Miguel Stéfano 3687, 04301-902 São Paulo, SP, Brasil

2. Corresponding author: rodrigo.fazani@gmail.com 
water status and of physiological and biochemical vital processes. Some of these responses include the low molecular weight organic solutes accumulation, also called compatible solutes, in a process known as osmotic adjustment (Bajji et al. 2001). In fact, osmotic adjustment has been considered an adaptation to water stress by which the net increase in the solutes concentration inside cells can assist in maintaining turgor, allowing plants to maintain metabolic activity, growth and productivity.

In order to acclimate and/or adapt to water deficits of different intensity levels, plants can accumulate free amino acids and proline (Rai 2002, Nayyar \& Walia 2003, Kusaka et al. 2005, Yamada et al. 2005), polyalcohols (Ramanjulu \& Bartels 2002) and carbohydrates (Pelleschi et al. 1997, Chaves et al. 2002). Among these, carbohydrates are key elements because they can be stored either in the form of polysaccharides with low osmotic activity as starch, or in the form of highly soluble and hygroscopic sugars such as sucrose and hexoses (Buckeridge et al. 2000, Whittaker et al. 2007).

In this sense, it is plausible that carbohydrateaccumulating plant species in specialized reserve organs, such as thickened roots may, during their growth, have the carbohydrates synthesis and accumulation affected by drought, or use them to generate osmotically active compounds through their degradation in response to this environmental stress. $V$. discolor Baker (Asteraceae) is an herbaceous perennial species native to Brazilian Cerrado, which survival is threatened by the growing invasion of exotic plants, especially African grasses. This plant accumulates inulin-type fructans in the tuberous roots, a soluble carbohydrate widely spread in regions where water availability is limited. Several studies have suggested that fructans confer resistance to drought or cold tolerance to plants, mainly due to their osmotically active capacity (Pilon-Smits et al. 1995, Livingston \& Henson 1998, Pilon-Smits et al. 1999, Van den Ende et al. 2000).

The study of carbohydrate reserves of native Atlantic Forest and Cerrado and its importance to the adaptation of these species in their natural environment has been extensively studied (Figueiredo-Ribeiro et al. 1986, Graziano et al. 1992, Vieira \& FigueiredoRibeiro 1993, Carvalho et al. 1997, Chu \& FigueiredoRibeiro 2002, Asega \& Carvalho 2004, Portes \& Carvalho 2006). However, despite this information, research on water relations and responses to water stress of tropical herbaceous native species that accumulate different types of carbohydrates, such as fructans are still scarce. The aim of this work was to evaluate the influence of water deficit of different intensities in carbohydrate accumulation in plants of $V$. discolor Baker during their initial growth.

\section{Materials and methods}

Plants of $V$. discolor Baker were obtained by germination of seeds collected in the Experimental Station and Biological Reserve of Mogi Guaçu, SP $\left(22^{\circ} 18^{\prime} \mathrm{S}, 47^{\circ} 11^{\prime} \mathrm{W}\right)$, and used in the experiments six months after transplantation. Plants were grown in individual pots $(2 \mathrm{~L})$ containing Cerrado soil and maintained under glasshouse conditions at the Department of Plant Physiology and Biochemistry of Instituto de Botânica, São Paulo, SP $\left(23^{\circ} 38^{\prime}\right.$ S, $\left.46^{\circ} 37^{\prime} \mathrm{W}\right)$, Brazil, during the experimental period. When presented the minimum of five fully expanded leaves, the plants were then submitted to different water regimes, as follow: Daily watered (DW) and water withholding for 14 days (WW) followed by re-watering at the $15^{\text {th }}, 16 \mathrm{t}^{\mathrm{t}}$ and $17^{\text {th }}$ days.

To avoid nutritional problems, the plants received nutrient solution from Clark (Clark, 1975) until the beginning of treatment. Samplings $(n=3)$ were carried in each treatment at time zero and at 3, 6, 9, 12, 15 and 18 days after the start of the experiment.

\section{Ecophysiological Parameters}

Soil moisture and soil water potential - Soil moisture (\%) was measured by gravimetric method (Blake $1965)$ and soil water potential $\left(\Psi_{w \text { soil }}\right)$ was measured using a dew point psychrometer (Decagon WP4 Model).

Relative water content and leaf water potential - Leaf water potential $\left(\Psi_{w \text { leaf }}, \mathrm{MPa}\right)$ was measured in the pre-morning period (05:00 AM to 06:00 AM), using a Scholander pressure pump (Model 1000, PMS Instrument Co, Albany, OR, USA), and according to Scholander et al. (1965). The leaf relative water content (RWC), expressed as percentage (\%),was determined according to Weatherley (1950).

\section{Biochemical Analysis}

Extraction of Soluble Carbohydrates - Leaf samples and tuberous roots of $V$. discolor from each treatment were collected and macerated in liquid nitrogen and lyophilized. The samples were separated into $0.5 \mathrm{~g}$ aliquots and subjected to exhaustive extraction with 
$80 \%$ ethanol at $80^{\circ} \mathrm{C}$ for $15 \mathrm{~min}$. centrifuged at $1,000 \mathrm{~g}$ for $15 \mathrm{~min}$ and the supernatants were then collected. This procedure was repeated three times, and all the supernatants from each sample were combined and concentrated in rotavapor at $40^{\circ} \mathrm{C}$ and resuspended in $15 \mathrm{~mL}$ of distilled water. The aqueous solutions were maintained at $-20{ }^{\circ} \mathrm{C}$ until analyzed (Carvalho et al. 1998). The concentrate was fractionated overnight at $5{ }^{\circ} \mathrm{C}$, by the addition of three volumes of ethanol, originating the fructooligo and fructopolysaccharide fractions after centrifugation at $1000 \mathrm{~g}$. The precipitate was resuspended in $3 \mathrm{ml}$ distilled water and constituted the fructopolysaccharide fraction and the supernatants were concentrated on rotary evaporator at $40{ }^{\circ} \mathrm{C}$ and constituted the of fructooligosaccharides fraction (Carvalho et al. 1998).

The total fructans contents in leaves and tuberous roots were estimated by quantification of free and combined fructose in the crude extracts and in the fructooligo and fructopolysaccharide fractions, by a ketose-specific modification of the anthrone reaction (Jermyn 1956), using fructose as standard. Soluble sugars were quantified by the phenol-sulfuric method (Dubois et al. 1956) using glucose (Sigma $\left.{ }^{\circledR}\right)$ as standard and reducing sugars were quantified in the fructooligosaccharide fractions using glucose $\left(\right.$ Sigma $\left.^{\circledR}\right)$ as standard (Somogyi 1945).

Statistical analysis - All the collected data was submitted to an analysis of variance, using the statistical software package BioEstat version 5.3 (Ayres et al. 2007). Differences between averages were evaluated with the Tukey test. The level of significance was set at a 5\% probability level. In addition, Pearson simple correlation analyzes were also performed between the evaluated parameters.

\section{Results and Discussion}

Soil moisture (figure 1) remained almost constant in DW plants with values above $20 \%$ throughout the experiment, demonstrating that daily watering was enough to keep the soil moisture close to field capacity. In WW plants, soil moisture values were below $10 \%$, achieved at 15 days, suggesting that soil moisture reached the permanent wilting point (PWP). These upper and lower limits of soil moisture are consistent with those observed by Medina \& Grohmann (1996) for savannah soils, which determined the average limits of field capacity and PWP of 28 and 10.4\%, respectively. Three days after re-watering, on day 18 of experiment, soil moisture values were similar to the DW treatment.
The $\Psi_{w \text { soil }}$ (figure 1) followed the variations in soil moisture, being the lowest value observed was $-8 \mathrm{MPa}$, at 12 days at WW plants. Similarly, rewatering promoted the increase of water potential with values close to the DW plants on day 18 . In control pots, $\Psi_{\text {w soil }}$ remained constant throughout the experiment.

The leaf RWC and $\Psi_{\text {w leaf }}$ (figure 2) showed that the plant-water relations accompanied changes in soil water availability. Soil moisture in the DW (figure 1) was enough to keep the plants well hydrated with minimum values of RWC and $\Psi_{w \text { leaf }}$ of $88 \%$ and $-0.5 \mathrm{MPa}$, respectively, keeping constant throughout the experiment. On the other hand, WW treatment decrease both the RWC and $\Psi_{\text {w leaf }}$ in leaves, with minimum values of $60 \%$ and $-1.3 \mathrm{MPa}$, respectively which was observed on the $15^{\text {th }}$ day after water suppression (figure 2). It is noteworthy that variations in $\Psi_{\text {w leaf }}$ in plants subjected to water suppression until the $15^{\text {th }}$ day were due, at least in part, to reductions leaf RWC since the lowest values of this parameter coincided with the lowest values of $\Psi_{\text {w leaf }}$ A different behavior was observed by Garcia et al. (2011) in plants of Vernonia herbacea, where it was verified that the reductions in the $\Psi_{\text {w leaf }}$ were due to the addition of solutes, reducing even more the water activity in the vegetal tissues, than to the reduction of the volumetric water content per se. As expected, the re-watering after the $15^{\text {th }}$ day increased $\Psi_{\text {w leaf }}$ and RWC of WW plants at levels similar to DW plants. The same pattern was explained by Mahdieh et al. (2008) in Nicotiana tabacum, where re-watering led to an increase in water potential and the recovery of all water relation parameters to a level like that of control plants.

The concentration of soluble sugars in leaf crude extracts remained almost constant in DW plants, with a small decrease between 3 and 9 days. On the other hand, plants subjected to WW treatment showed higher accumulation of soluble sugars at day 15 , with an increase of $30 \%$ over the concentration of soluble sugars in DW ones. After re-watering on $15^{\text {th }}$ day there was a decrease in soluble sugars concentration (figure 3). Total fructans contents remained almost constant throughout the experiment in DW plants, with values up to $10 \mathrm{mg} \mathrm{g}^{-1}$ dry mass. On the other hand, plants subjected to water suppression showed total fructans levels three times higher on the $15^{\text {th }}$, coinciding with the period of highest water deficit experienced by the plants (figure 4).

The fructopolysaccharides showed a profile of small variations, with similar values between 
the different treatments (figure 4). Fractions of oligosaccharides presented a gradual increase from day 9 in both plant groups, daily watering and water suppression; however, this increase was more pronounced in water suppression plants subjected to suspension of watering. In these plants, fructooligosaccharides also reached values three times higher than those observed in control plants, on day 15 , with subsequent decrease on day 18 , three days after re-watering. Reducing sugars also had the highest concentration at 15 days only in plants subjected to water suppression. Subsequently, reducing sugars presented a considerable decrease at 18 days, three days after re-watering (figure 4).

In general, the variations observed in carbohydrate contents in $V$. discolor were closely related to changes in water status. In fact negative correlations between the soluble sugars, total fructans, fructooligosaccharides and reducing sugars concentrations with $\Psi_{\text {w leaf }}$ $(r=-0.69 ; r=-0.67 ; r=-0.55 ; r=-0.83 ;$ respectively $)$

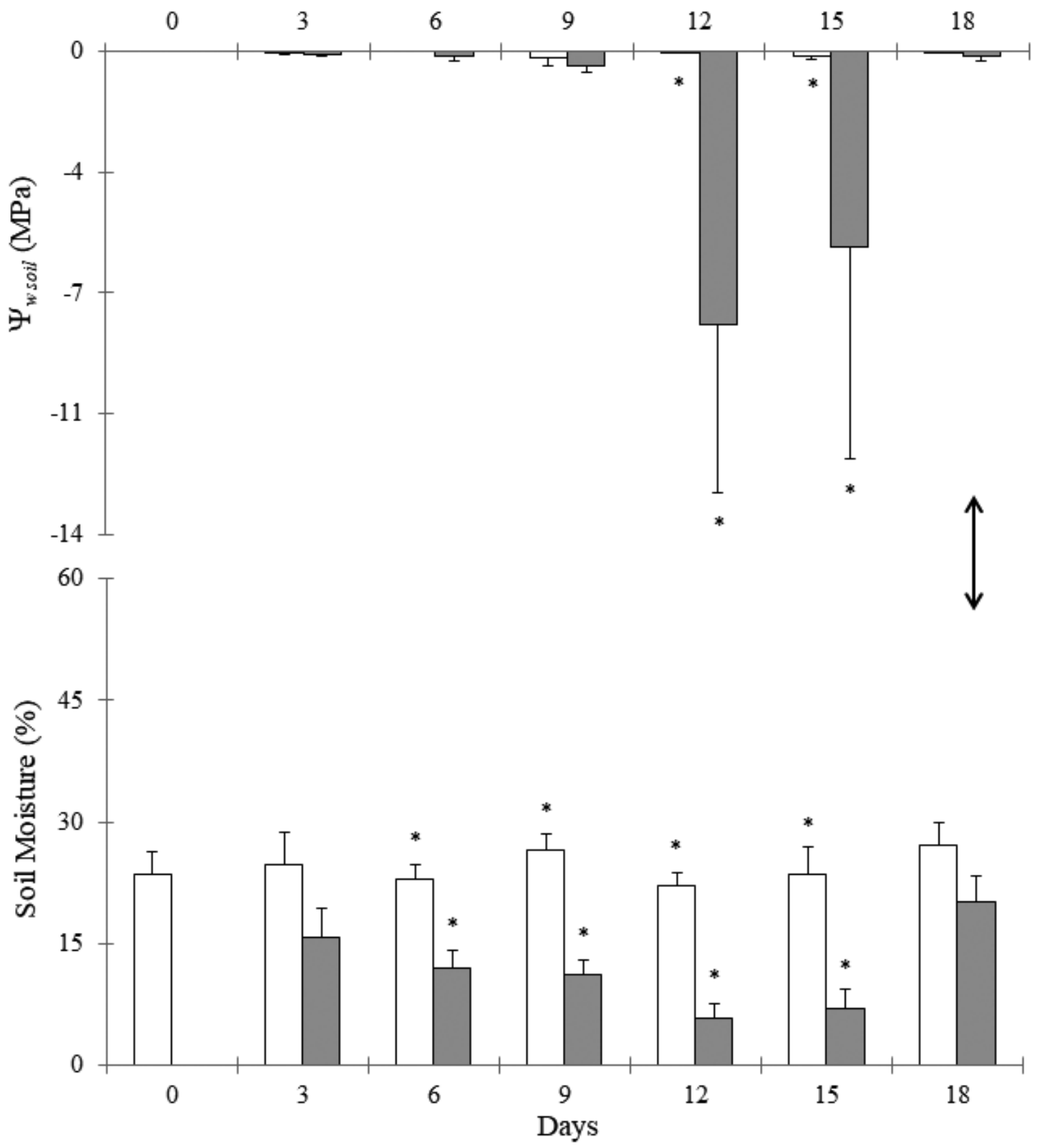

Figure 1. Soil moisture (\%) and soil water potential $\left(\Psi_{\mathrm{w} \text { soil }}\right.$, MPa) in plants of Viguiera discolor under daily watering ( $\left.\square\right)$ and water suppression ( $\mathbf{\square}) . \downarrow=$ day of re-watering. * Significant difference between treatments at $\mathrm{P}<0.05(\mathrm{n}=3 \pm \mathrm{SD})$. 
and also with the RWC $(\mathrm{r}=-0.71 ; \mathrm{r}=-0.70 ; \mathrm{r}=-0.64$; $r=-0.83$; respectively) was observed. On the other hand, in the tuberous roots, we observed positive correlations in the concentration of total fructans, fructooligo and fructopolysaccharides due to changes in soil water availability $\left(\Psi_{\mathrm{w} \text { soil }}: \mathrm{r}=0.52 ; \mathrm{r}=0.53\right.$; $\mathrm{r}=0.63$; respectively and Soil Moisture: $\mathrm{r}=0.84$; $\mathrm{r}=0.88 ; \mathrm{r}=0.94$; respectively) as changes in $\Psi_{\mathrm{w} \text { leaf }}$ $(\mathrm{r}=0.58 ; \mathrm{r}=0.62 ; \mathrm{r}=0.72$; respectively $)$ and in RWC $(r=0.58 ; r=0.61 ; r=0.72$; respectively). These results suggest that reductions in plant water potential are due not only to reductions in water content as a result of low soil moisture, but also to the increase in low molecular weight carbohydrates (e.g. fructooligosaccharides and reducing sugars fractions), for their activity in osmotic adjustment in response to the water deficit imposed. The increase of fructooligosaccharides, in ratio fructopoly:fructooligosaccharides and in reducing sugars in response to water deficit was observed by DiasTagliacozzo et al. (2004) and Garcia et al. (2011),

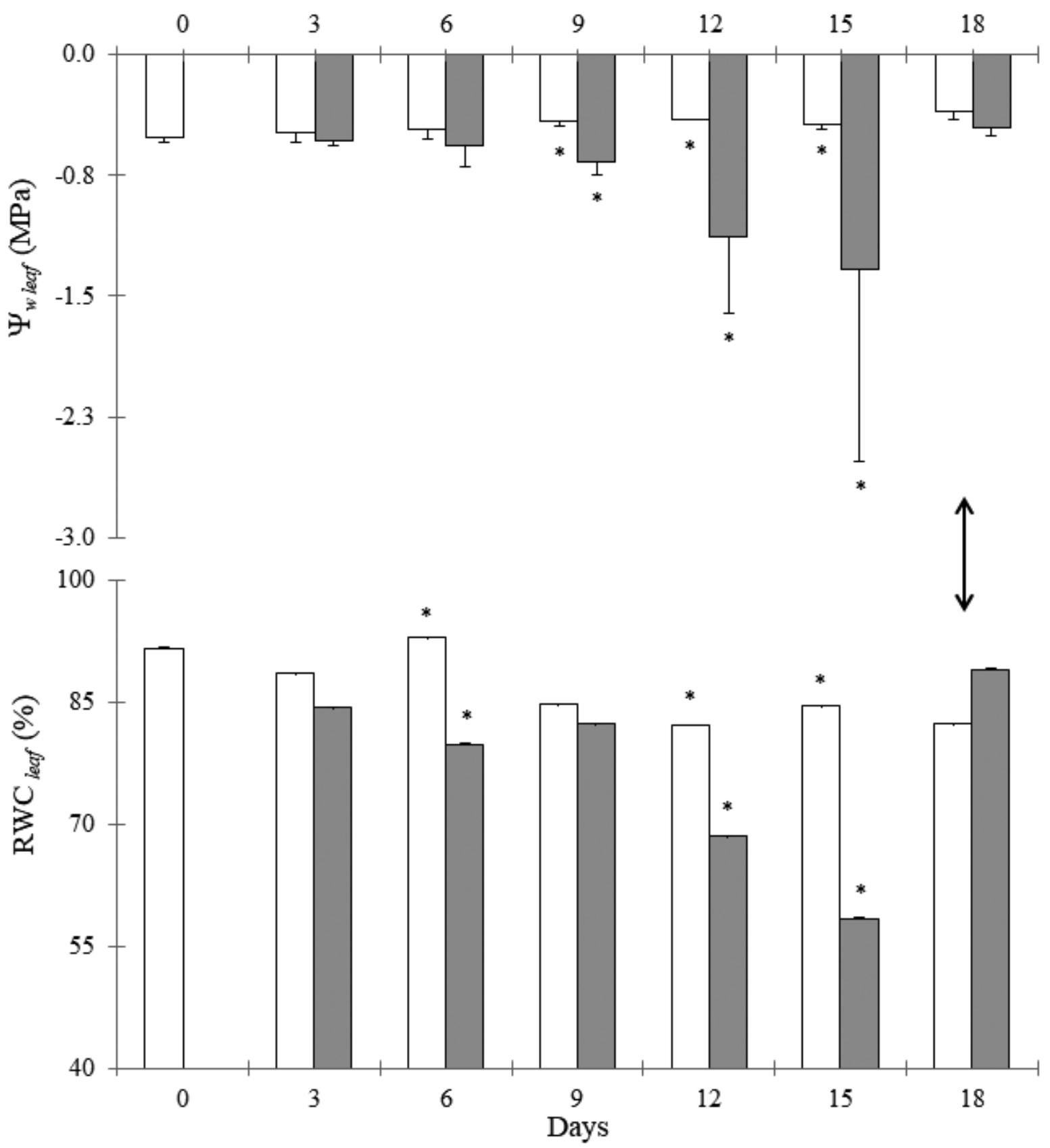

Figure 2. Relative content of water $(\mathrm{RCW}, \%)$ and leaf water potential $\left(\Psi_{\mathrm{w} \mathrm{leaf}}, \mathrm{MPa}\right)$ in leaves of plant Viguiera discolor under daily watering ( $\square$ ) and water suppression ( $\square$ ). $\downarrow=$ day of re-watering. $*$ Significant difference between treatments at $\mathrm{P}<0.05$ (n $=3 \pm \mathrm{SD}$ ). 
respectively in rhizophore fragments and in intact plants of $V$. herbacea, another inulin-accumulating species of the Cerrado.

The parameters of total fructans, fructooligo, fructopolysaccharides fractions and reducing sugars (figure 5) in tuberous roots showed a different behavior from that observed in leaves. The highest concentration of these carbohydrates in the storage roots compared to leaves is consistent with their reserve role in this species. The temporal variation in the processes of synthesis, degradation and translocation of these carbohydrates in $V$. discolor (Isejima \& FigueiredoRibeiro 1993) explains the observed variations over the experimental period. The higher content of fructooligo and fructopolygosaccharides fractions between the $3^{\text {rd }}$ and $6^{\text {th }}$ day (figure 5) followed by reduction mostly between the $12^{\text {th }}$ and $15^{\text {th }}$ days after water suppression suggests that these carbohydrates may have been used in the osmotic adjustment of shoots in response to the water deficit imposed.

After re-watering (from $15^{\text {th }}$ to $18^{\text {th }}$ days) WW plants presented a decrease in the leaf carbohydrate levels showing similar values to DW plants (figure 4). Conversely, in the tuberous roots of plants under water suppression, carbohydrate contents increased significantly after the return of water availability in the soil (figure 5). Reserve underground organs are the main source of carbohydrates, where the content and composition of reserve compounds in Cerrado herbaceous species exhibit the presence of large amounts of soluble carbohydrates such as fructans, sucrose, glucose, fructose and oligosaccharides. Thus, the regrowth of herbaceous plants after some type of abiotic stress, such as seasonal drought, cold or fire requires carbon mobilization, which in the absence of immediate photoassimilates, this carbon comes from reserve mobilization (Figueiredo-Ribeiro et al. 1986, Moraes et al. 2016).

In this study we observed an increase in the proportion of the monosaccharides, mainly glucose and fructose when compared to other different sugars that are part of inulin series. This result is expected since the highest concentrations of free fructose and other oligosaccharides coincided with the period in which the plants were subjected to water stress, suggesting that these osmolytes acted on the maintenance of cell turgor (Dias-Tagiacozzo et al. 2004). As fructans can be rapidly mobilized to fructose and sucrose, products of their depolymerization, these compounds can act in the maintenance of the water status of plants kept under water deficiency, where the accumulation of these solutes can contribute to the decrease of cellular osmotic potential, offering an alternative mechanism for osmoregulation (Spollen \& Nelson 1994, Moraes et al. 2016).

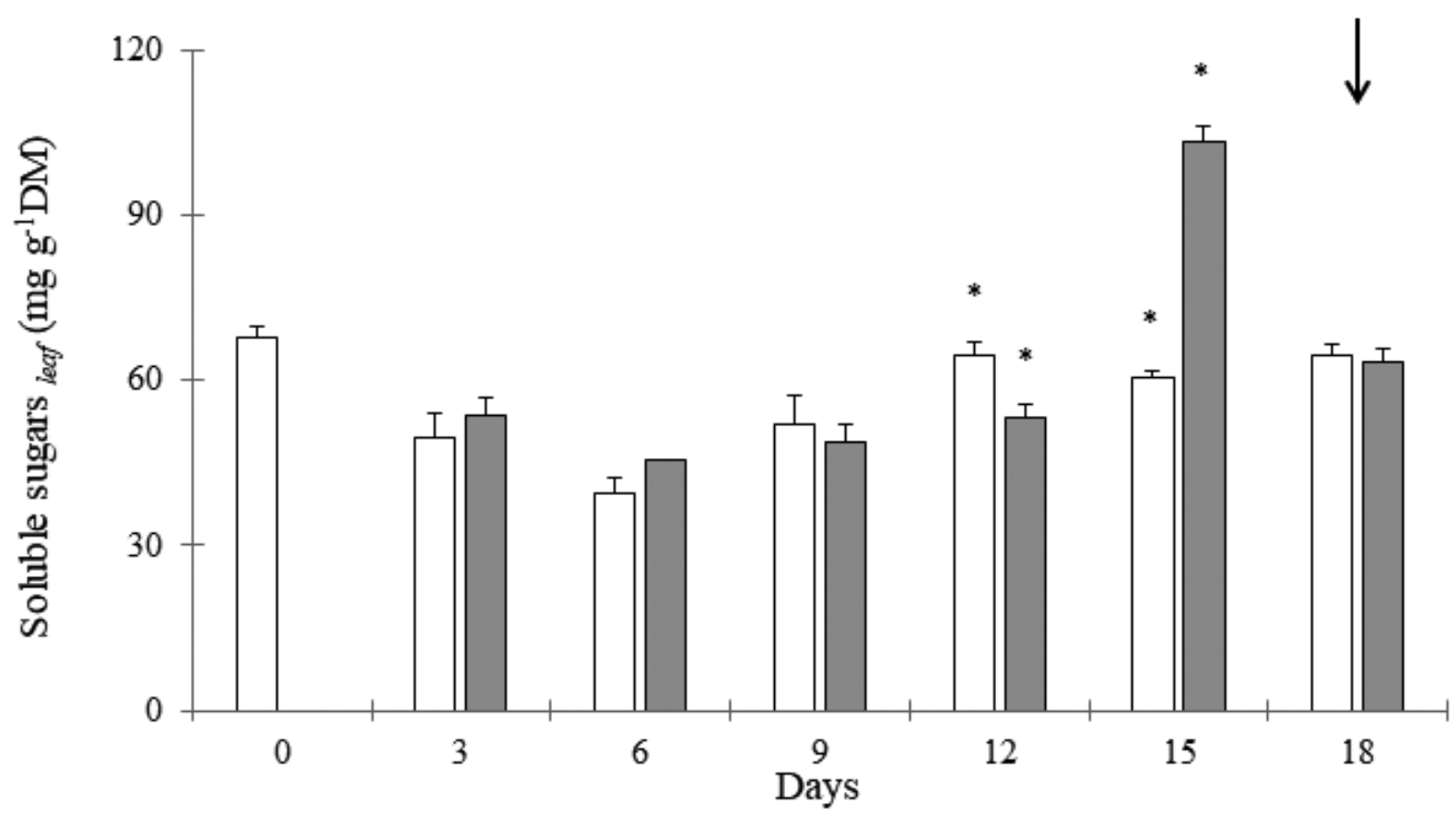

Figure 3. Soluble sugars $\left(\mathrm{mg} \mathrm{g}^{-1} \mathrm{DM}\right)$ in leaves of plant Viguiera discolor under daily watering $(\square)$ and water suppression $(\boldsymbol{\square})$. $\downarrow=$ day of re-watering. * Significant difference between treatments at $\mathrm{P}<0.05(\mathrm{n}=3 \pm \mathrm{SD})$. 


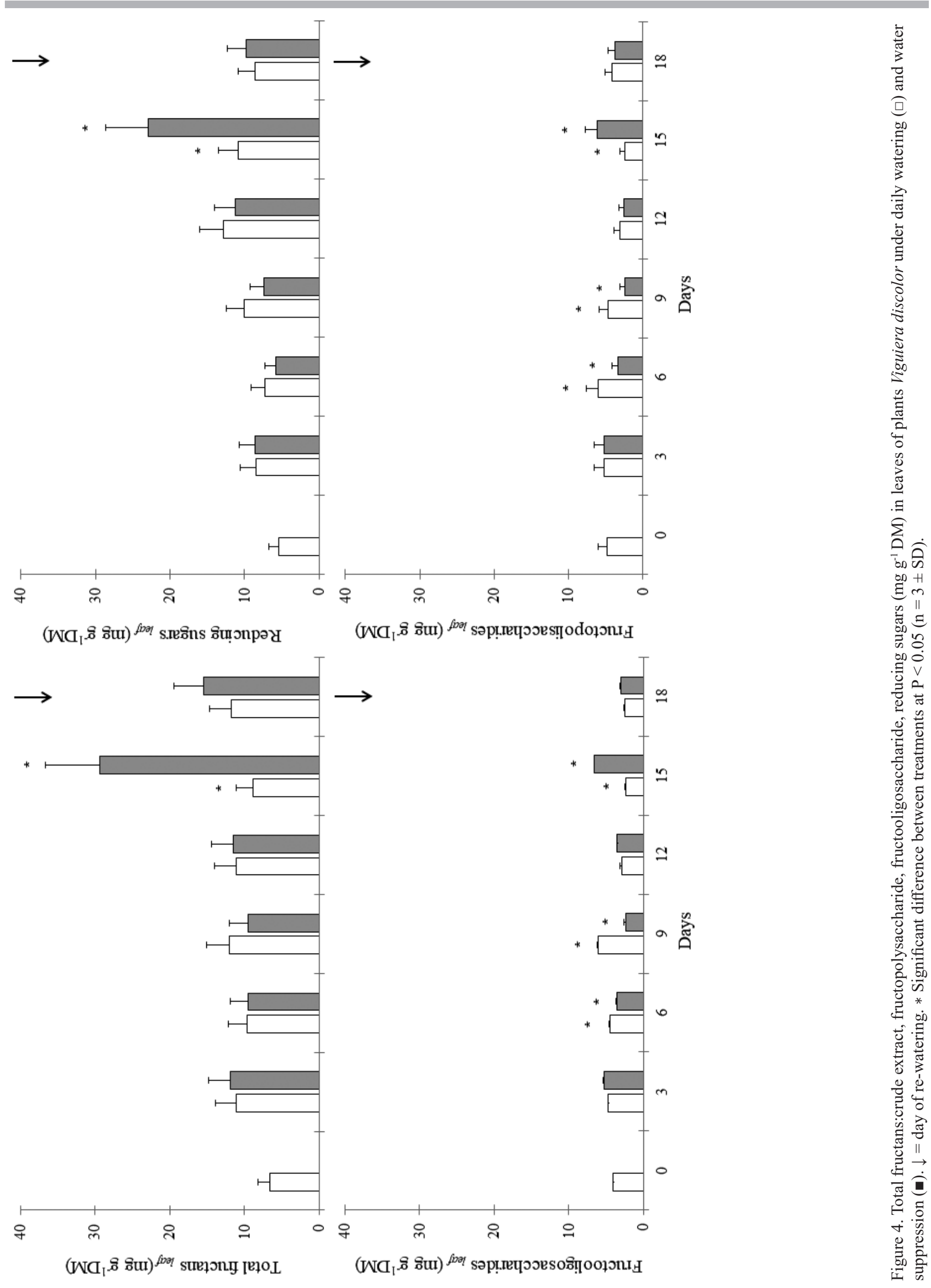




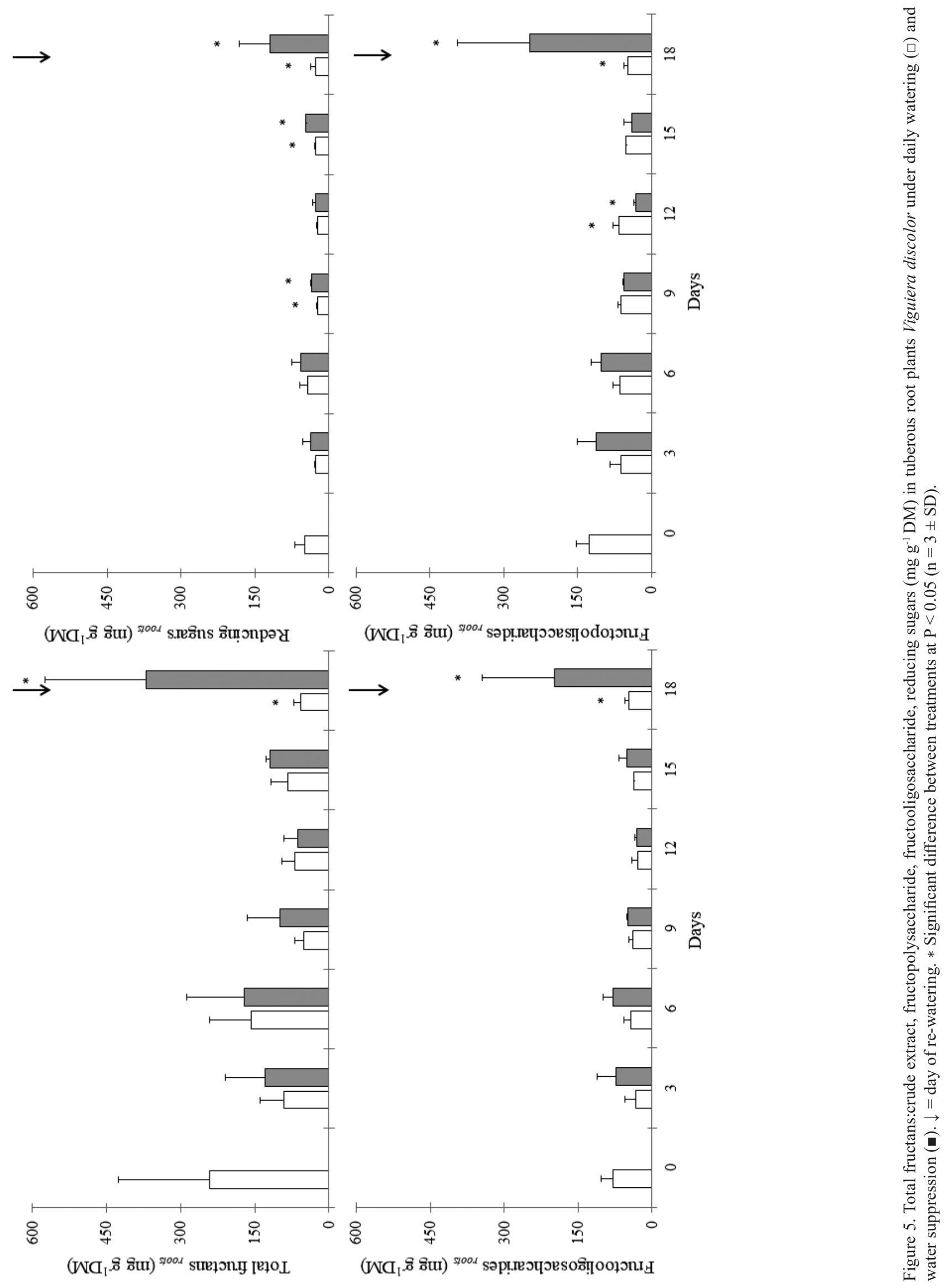


Our results suggested that carbohydrates play an important role in the responses of $V$. discolor plants to drought during its initial growth. If not otherwise, plants submitted to water withholding showed a significant increase, in fructooligo and fructopolysaccharides, especially of the lower degree of polymerization, fructose and sucrose. Changes in carbohydrate levels presented over the experiment a close correlation with changes in soil water availability and plants water status. The increase of these low molecular weight sugars is involved in osmotic adjustment protecting plants of $V$. discolor against dehydration, acting as an important strategy to plant establishment in its natural environment of occurrence.

\section{Acknowledgment}

This work was supported by FAPESP (09/015700). R.F.E.S, A.P.O.S and V.P.C. tanks CAPES and $\mathrm{PIBIC} / \mathrm{CNPq}$ for awarded fellowships. M.A.M.C and E.A.S is a CNPq research fellow.

\section{Literature cited}

Asega, A.F. \& Carvalho, M.A.M. 2004. Fructan metabolising enzymes in rhizophores of Vernonia herbacea upon excision of aerial organs. Plant Physiology and Biochemistry 24: 313-319.

Ayres, M., Ayres Jr., M., Ayres, D.L. \& Santos, A.S. 2007. BioEstat: aplicações estatísticas nas áreas das ciências biomédicas. Sociedade Civil Mamirauá, Brasília.

Bajji, M., Luttss, S., Kinet J.M. 2001. Water deficit effects on solute contribution to osmotic adjustment as a function of leaf ageing in three durum wheat (Triticum durum Desf.) cultivars performing differently in arid conditions. Plant Science 160: 669-681.

Blake, G.R. 1965. Bulk density. In: C.A. Black, D.D. Evans, J.L. White, L.E. Ensminger \& F.E. Clark (eds.). Methods of soil analysis. American Society of Agronomy, pp.374-390.

Buckeridge, M.S., Tiné, M.A.S. \& Santos, H.P. 2000. Polissacarídeos de reserva de parede cellular em sementes. Estrutura, metabolismo, funções e aspectos ecológicos. Revista Brasileira de Fisiologia Vegetal 12: 137-162.

Carvalho, M.A.M., Pinto M.M. \& Figueiredo-Ribeiro, R.C.L. 1998. Inulin production by Vernonia herbacea as influenced by mineral fertilization and time of harvest. Revista Brasileira de Botânica 21: 281-285.

Carvalho, M.A.M., Zainan, L.B.P., Dietrich, S.M.C. 1997. Growth and fructan content of plants of Vernonia herbacea (Asteraceae) regenerated from rhizophores. New Phytologist, 136: 153-161.
Chaves, M. M., Pereira, J. S., Maroco, J., Rodrigues, M. L., Ricardo, C. P. P., Osorio, M. L., Carvalho, I., Faria, T. \& Pinheiro, C. 2002. How plants cope with water stress in the field. Photosynthesis and growth. Annals of Botany, 89: 907-916.

Chu, E.P. \& Figueiredo-Ribeiro, R.C.L. 2002. Growth and carbohydrate changes in shoot cultures of Dioscorea species as influenced by photoperiod, exogenous sucrose and cytokinin concentrations. Plant Cell Tissue and Organ Culture 70: 241-249.

Clark, R.B. 1975. Characterization of phosphatase of intact maize roots. Journal of Agriculture and Food Chemistry 23: 458-460.

Dias-Tagliacozzo, G.M., Itaya, N.M., Carvalho, M.A.M., Figueiredo-Ribeiro, R.C.L. \& Dietrich, S.M.C. 2004. Fructans and water suppression on intact and fragmented rhizophores of Vernonia herbacea. Brazilian Archives of Biology and Technology 47: 363-373.

Dubois, M., Gilles, K.A., Hamilton, J.K., Rebers, P.A \& Smith, F. 1956. Colorimetric method for determination of sugars and related substances. Analytical Chemistry 28: 350-356.

Figueiredo-Ribeiro, R.C.L., Dietrich, S.M.C., Chu, E.P., Carvalho, M.A.M., Viera, C.C.J., Graziano, T.T. 1986. Reserve carbohydrates in underground organs of native Brazilian plants. Revista Brasileira de Botânica 9: 159-166.

Garcia, P.M.A., Asega, A.F., Silva, E.A. \& Carvalho, M.A.M. 2011. Effect of drought and re-watering on fructan metabolism in Vernonia herbacea (Vell.) Rusby. Plant Physiology and Biochemistry 49: 664-670.

Graziano, T.T., Dietrich, S.M.C. \& Figueiredo-Ribeiro, R.C.L. 1992. Characterization of starch of the underground system of Xanthoxoma sagittifolium (L.) Schott (Araceae) during plant development. Revista Brasileira de Fisiologia Vegetal 4: 7-10.

Isejima, E.M. \& Figueiredo-Ribeiro, R.C.L. 1993. Fructan variations in tuberous roots of Viguiera discolor Baker (Asteraceae): the influence of phenology. Plant and Cell Physiology 34: 7233-727.

Jones, H.G. \& Corlett, J.E. 1992. Current topics in drought physiology. Journal of Agricultural Science 119: 291-296.

Kusaka, M., Ohta M. \& Fujimura, T. 2005. Contribution of inorganic components to osmotic adjustment and leaf folding for drought tolerance in pearl millet. Physiologia Plantarum 125: 474-489.

Livingston, D.P. \& Henson, C.A. 1998. Apoplastic sugars, fructans, fructan exohydrolase, and invertase in winter oat: responses to second phase cold hardening. Plant Physiology 116: 403-408.

Mahdieh, M., Mostajeran, A., Horie, T. \& Katsuhara, M. 2008. Drought stress alters water relations and expression of PIP-Type aquaporin genes in Nicotiana tabacum plants. Plant Cell Physiology 49: 801-813. 
Medina, H.P.\& Grohmann, F. 1996. Disponibilidade de água em alguns solos sob cerrado. Bragantia 25: 65-75.

Moraes, M.G., Carvalho, M.A.M., Franco, A.C., Pollock, C.J. \& Figueiredo-Ribeiro, R.C.L. 2016. Fire and drought: soluble carbohydrate storage and survival mechanisms in herbaceous plants from the Cerrado. BioScience 66: 107-117.

Nayyar, N. \& Walia, D.P. 2003. Water stress induced proline accumulation in contrasting wheat genotypes as affected by calcium and abscisic acid. Biologia Plantarum 46: 275-279.

Pelleschi, S., Rocher, J.P. \& Prioul, J.L. 1997. Effect of water restriction on carbohydrate metabolism and photosynthesis on mature maize leafs. Plant, Cell and Environment 20: 493-503.

Pilon-Smits, E.A.H., Terry, N., Sears, T. \& Van Dun, K. 1999. Enhanced drought resistance in fructan-producing sugar beet. Plant Physiology and Biochemistry 37: 313-317.

Pilon-Smits, E.A.H., Ebskamp, M.J.M., Paul M.J., Jeuken, M.J.W., Weisbeek, P.J.\& Smeekens, S.C.M. 1995. Improved performance of transgenic fructanaccumulating tobacco under drought stress.Plant Physiology 107: 125-130.

Portes, M.T. \& Carvalho, M.A.M. 2006. Spatial distribution of fructans and fructan metabolizing enzymes in rhizophores of Vernonia herbacea (Vell.) Rusby (Asteraceae) in different development phases. Plant Science 170: 624-633.

Ramanjulu, S. \& Bartels, D. 2002. Drought- and disecation-induced modulation of gene expression in plants. Plant, Cell and Environment 25:141-151.

Scholander, P.F., Hammel, H.T., Bradstreet, E.D. \& Hemmingsen, E.A. 1965. Sap pressure in vascular plants. Science 148: 339-346.
Somogyi, M. 1945. A new reagent for the determination of sugars. Journal of Biological Chemistry 160:61-63.

Spollen, W.G. \& Nelson, C.J. 1994. Response of fructan to water deficit in growing leaves of tall fescue, Plant Physiology 106: 329-336.

Van Den Ende, W., Vandenbraden, K., Van Laere, A., \& De Roover, J. 2000. Drought induces fructan synthesis and 1-SST (sucrose:sucrose fructosyltransferase) in roots and leaves of chicoryseedlings (Chicorium intybus L.). The Plant of Journal 210: 808-814.

Vieira, C.C.J. \& Figueiredo-Ribeiro, R.C.L. 1993. Fructose-containing carbohydrates in the tuberous root of Gomphrena macrocephala St.-Hil. (Amarantaceae) at different phonological phases. Plant, Cell and Environmet 16: 919-928.

Weatherley, P.E. 1950. Studies in the water relations of the cotton plant. I. The field measurement of water deficits in leaves. New Phytologist 49: 81-97.

Whittaker, A., Martinelli, T., Farrant, J.M., Bochichio, A. \& Vazzana, C. 2007. Sucrose phosphate synthase activity and the co-ordination of carbon partitioning during sucrose and amino acid accumulation in desiccation-tolerant leaf material of the $\mathrm{C} 4$ resurrection plant Sporobolus stapfianus during dehydration. Journal of Experimental Botany 58: 3775-3787.

Yamada, N., Morishita, H., Urano, K., Shiozaki, N., Yamaguchi-Shinozaki, K., Shinozaki, K. \& Yoshiba, Y.2005. Effects of free proline accumulation in petunias under drought stress. Journal of Experimental Botany 56: 1975-1981.

Zobayed, S.M.A, Afreen, F. \& Kozai, T. 2007. Phytochemical and physiological changes in the leaves of St John's wort plants under a water stress condition. Environmental and Experimental Botany 59: 109-116. 